\title{
Fool's Gold? Constitution, Sovereignty and the Golden Share in Embraer-Boeing Case
}

\author{
Rodrigo Oliveira Salgado \\ Universidade Presbiteriana Mackenzie \\ Fábio Sampaio Mascarenhas \\ Universidade de São Paulo \\ Marcus Vinícius Silva de Oliveira \\ Universidade Presbiteriana Mackenzie
}

\begin{abstract}
The object of this article is to analyze the Golden Share (Ação de Classe Especial) as an instrument of economic sovereignty. It questions whether, legally, there is a possibility of imposing on the Executive Branch the use of the veto power inherent to the golden share in cases where a joint venture of a foreign company with a state-owned company represents a risk to national sovereignty. The hypothesis is that based on the principle of economic sovereignty (art. 170, I), there is an express obligation to the administration to veto in the case where a joint venture of a foreign company with a national company harms the domestic market (art. 219). It concludes that in the mentioned cases there is the possibility of imposing the use of the veto power to the Executive Branch, in case of omission, it is competence of the National Congress, and subsidiarily to the Judiciary Branch, due to the imposing nature of the constitutional principle of economic sovereignty.
\end{abstract}

Keywords: golden share, economic sovereignty, parallelism of forms

\section{INTRODUCTION}

On July 5, 2018, representatives of the Brazilian company EMBRAER and the US company BOEING signed a memorandum of understanding that embodies the closing of a joint venture that had been in dialogue since the previous year between the companies ${ }^{1}$. In it, the creation of a company in commercial aviation was foreseen, which had as a division of its capital stock the proportion of eighty percent to the US company and twenty percent to the Brazilian company, which gave control to the former, as well as a joint venture in the area of defense.

Faced with this scenario, this article, given the dimension of the case, intends to analyze the relevance of the golden share instrument for national ${ }^{2}$ economic sovereignty.

To this end, two questions are raised: (i) is it legally possible, with regard to the veto power inherent in the golden share ${ }^{3}$, considering the Brazilian constitutional-economic order, an omission of the Federal 
Executive Branch? (ii) if such omission occur, would the National Congress have the competence to analyze it?

Faced with such questions, it is hypothesized that based on the principle of economic sovereignty (art. $\left.170, I^{4}\right)$, there is an express obligation of the administration to veto, in the case that a joint venture or a corporate reorganization (merger, acquisition, spin-off, etc.) of a foreign company with a national stateowned company harms the domestic market (art. 219) ${ }^{5}$. If this obligation is not exercised, it will be up to the National Congress, by force of the principle of the parallelism of forms, and as an expression of popular sovereignty, to make this designation. It remains for the Judiciary, in the exercise of its subsidiary power, to make a last decision for the protection of economic sovereignty.

In order to corroborate, or not, this hypothesis, in the first item we have contributions on the emergence of the golden share in face of the conjuncture that motivated its creation. In the second item, the context that motivated the emergence of the golden share in Brazil is outlined. Finally, the Embraer-Boeing case and the constitutional provisions relevant to economic sovereignty are highlighted in greater detail, in order to explain the intrinsic relationship between the extinction of a golden share and the violation of these provisions.

\section{THE ORIGIN OF GOLDEN SHARE AND NEOLIBERALISM}

The Golden Share is a mechanism that has the function of carrying out the transfer of corporate control of state-owned companies, keeping under State control powers that safeguard national interests, to prevent the participation of foreign companies in strategic sectors of the economy, therefore called "golden share". In practice, the share was a share title that represented a unit of the capital stock, in order to give the State, its holder, special prerogatives, disproportionate to its participation, in order to prevent the entry of foreign shareholders in the company, satisfying the public interest (KRUEGER, 2008, p. 186; FERRAZ, 2009).

The understanding of its importance is intrinsically associated with the historical conjuncture in which the action was established. Its emergence occurs in the 1970s, in a context of advancing financialization ${ }^{6}$ and neoliberalism ${ }^{7}$, when privatization entered the global debate through the premise that by transferring to private individuals the control of state-owned companies, it would add greater value to their assets and increase, as a corollary, their aggregate welfare (KRUEGER, 2008, p. 188; FERRAZ, 2009).

Given this function, the first place to adopt the golden share in 1979 was the United Kingdom under Margaret Thatcher. In that context, the major factor for the application of the golden share was the influence of neoliberal ideas that preached the need to reduce public spending, especially as a result of the economic crisis that the United Kingdom faced between the late 1970s and early 1980s. This influence is also demonstrated in the government's intention to reduce state intervention either in the administration of companies or in the union power of state workers. Besides the assumptions of competitiveness and efficiency that state-owned companies should meet; the dispersion of shareholder ownership by workers and the reduction of loans granted by the Public Sector Borrowing Requirement (PSBR) (KRUEGER, 2008, p. 186).

Thus, in this scenario of decreasing state interventionism, the golden share represented an influential legal mechanism for the protection of state interests in several cases of privatization that took place there. Examples include British Aerospace in 1981, Cable \& Wireless in 1981, Amersham International in 1982, Britoil in 1982, Sealink in 1984, Enterprise Oil in 1984, Jaguar in 1984, British Telecom in 1984, British Gas in 1986, Rolls-Royce in 1987, British Airports Authority in 1987, British Petroleum in 1987, National Power in 1993, and British Steel in 1998 (FERRAZ, 2009, pp.425-469; COX, 1987; LIJPHART, 1999).

The origin of the concept of veto power is confused with the origin of the share itself, since it is an intrinsic characteristic of the latter. It arose in the United Kingdom as an attribution to the State to veto the dissolution of a state-owned company or the creation of new shares. The most classic example of the exercise of this power in that country was the acquisition of Britoil by British Petroleum in 1987. At that time, faced with this obstacle generated by the action, there was a political agreement to sign the acquisition (FERRAZ, 2009, p.426; COX, 1987; LIJPHART, 1999, KRUEGER, 2008, pp.188-189). 
Another country of reference for the understanding of this action was France, where the so-called action spécifique was instituted by Law no. 86.912 of August 6, 1986, in the context of the first stage of the French privatization program dated between 1986 and 1988, with the objectives of reducing the public deficit and promoting the development of a capitalisme populaire, linked to the securities market. Some practical examples of its application occurred in Société National Elf-Aquitaine in 1986, Compagnie des Machines Bull in 1987, Agence Havas, also in 1987, and Société Matra, also in 1987, Thomson S.A and Thonsom CSF in 1997 (BORDE; PONCELET, 1994, pp. 269-302; KRUEGER, 2008, p. 199).

The so-called action spécifique, through article 7 of Law 93.923, would guarantee to the French State the power of veto in deliberations involving the transfer or encumbrance of the company's assets, capable of harming national interests, a veto that could be exercised according to the procedure set forth in Decree 93.1296 (BORDE; PONCELET, 1994, pp. 269-302; KRUEGER, 2008, p. 199).

In Italy, the so-called special poteri speciali appeared through Decree-Law no. 332 of May 31, 1994, amended and converted into Law no. 474 of July 30, 1994. The great innovation of the Italian model refers to the non-dependence of the privatized company's ownership of the shares that made up the capital stock. It was also foreseen in the institute that before the transfer of the state-owned company's share control to the private sector, specifically in the defense, transportation, telecommunications, energy and other public service sectors, there could be a submission to statutory reform, in order to insert in the by-laws a clause with a special poteri speciali, being the Council of Ministers' designation to determine which companies would be subject to this reform. Three paradigmatic cases of the institute were the privatization of Eni s.p.a, in 1995, of Stet, s.p.a, and of Telecom Italia s.p.a in 1997 (KRUEGER, 2008, p. 203).

The Italian poteri speciali provided for a veto on resolutions concerning the dissolution, split or merger of the company, the transfer of a business establishment, the moving of the registered office abroad, the change of the company's purpose and the amendment of the clause in the by-laws regarding poteri speciali (cf. paragraph "c" of art. 2, comma 1, of Decree-law n.332) (BELVISO, 1997, pp. 103-110; SODI, 1996, p. 377).

Thus, the most relevant external examples of the use of the "golden share" are contextualized in a neoliberal scenario, in which the decrease of state intervention accompanied by the privatization of companies that operate in strategic economic sectors threatens the public interest. In Brazil, this process has similar characteristics. With the advance of neoliberalism in the country from the 1990s on, the National Privatization Program (NPD) includes the legal provision of the golden share.

Thus, in the following section we will discuss how neoliberalism advanced in Brazil, in order to contextualize the insertion of this action in our legal system in the 1990s.

\section{THE NATIONAL PRIVATIZATION PROGRAM (NPD) AND THE EMERGENCE OF GOLDEN SHARE IN BRAZIL}

In the early 1990s, at the end of José Sarney's government (1985-1990), the developmentalist debate was seen as synonymous with backwardness. The State was seen as inefficient, even in strategic sectors, in counterpoint to private initiative that appeared as representing dynamism and efficiency. The political moment was marked by the inauguration of Fernando Collor - the first elected president since 1960 inflation exceeded $80 \%$ per month and the economy was stagnant. Collor's discourse was based on denouncing corruption, catering to the underprivileged strata of society, and promoting structural reforms. However, these reforms broke with the Brazilian model based on high state intervention and tariff protection (COSTA, 2016, p. 74).

Lavínia Barros Castro (2005, pp. 139-142) states that the economic plans Collor I and II not only failed to eliminate inflation, but also resulted in recession and loss of credibility of savings institutions. This "reform process", initiated in the Collor government, continued in the Itamar Franco government (19921995), which was responsible for establishing the foundations of the stabilization program that marked the Fernando Henrique Cardoso government.

The period denoted a change in the development model that begins especially in the 1970 s, when, as André Ramos Tavares (2015, pp. 1047-1066) states, there was a decline in the power of the State to 
implement its decisions, which gained dramatic contours in the face of the so-called "economic globalization" and its intense mobility responsible for promoting the strength of international capital ${ }^{8}$.

In the legislative sphere, Law number 8.031, of April 12th 1990, created the National Privatization Program (NPD). In it, the fundamental objectives were the reorganization of the strategic position of the state in the economic domain, through the transfer to private initiative of activities supposedly badly explored by the public power; the reduction of the public debt, in order to contribute to the sanitation of the public sector finances, through the resumption of investments in privatized companies; the contribution to the modernization of the Brazilian industrial park, in order to increase its competitiveness and strengthen the business capacity in the various sectors of the economy; the limitation of concentration of public administration efforts in those activities in which the presence of the State was fundamental for the achievement of national priorities; and the contribution to the strengthening of the capital market through the increase of securities offerings and the democratization of ownership of the capital of companies that would be privatized (BRASIL, 1990).

With respect to the golden share, this law provides for the competence of the Steering Committee to create the action (article 6, XIII), which would be underwritten by the Union (article $6, \S 2$ ). In addition, in its article 8 , there is the provision that whenever there were justified reasons, the Union would hold, directly or indirectly, special class shares in the social capital of privatized companies, which would give it veto power in certain matters, which should be characterized in the companies' by-laws. This legal provision was subsequently regulated by Decree n. 1,204 of July 29, 1994, which provided in its article 43 that even if there were justifiable reasons, the Union would hold special class shares in the social capital of privatized companies, which would confer veto power on certain matters provided for in the by-laws" ${ }^{9}$.

In 1999, the Federal Government fought a fierce legal battle to veto the sale, by the controllers of the Empresa Brasileira de Aeronáutica S.A. (Embraer) to a French group, of $20 \%$ of the common shares issued by the company. At the time it was discussed whether the sale could be qualified as a transfer of shareholding control and, in this sense, whether it would be subject to the Union's veto (SILVA, 2000, pp. 197-217).

This posture of the Union fighting for the veto of the sale of Embraer. years later, in a context also neoliberal, but aggravated by political illegitimacy, was not repeated. Thus, in 2018 the corporate transaction between Embraer and Boeing was completed, and the possibility was even discussed by the Federal Court of Audit to give up the golden share.

In light of this, we will now look specifically at this case, in dialog with the principle of national sovereignty.

\section{THE EMBRAER CASE, THE EXTINCTION OF THE GOLDEN SHARE AND BRAZILIAN ECONOMIC SOVEREIGNTY}

\section{The Embraer Case and the Golden Share}

The operation in the Embraer case must necessarily be analyzed under the global prism. Given the restricted participation of agents ${ }^{10}$, the relevant geographic market in which it is inserted is, par excellence, global. In this context, the Oliver Wyman report points out that between 2018 and 2028 the global aircraft market should have a growth rate of $3.7 \%$ per year, jumping from 26,307 in 2018 to 37,978 in ten years ${ }^{11}$.

Although a steady growth of the fleet is verifiable, the annual increase of about 1,183 aircraft is indicative of the natural restriction of the market structure. Despite the forecasts of constant growth of tons transported $^{12}$, barriers to entry such as high investment in fixed capital, the need for highly skilled labor and mastery of the latest technology are insurmountable issues for the emergence of a large number of new players.

Exactly because of this, consolidated companies and leaders in the large commercial aviation market such as Airbus and Boeing tend to have the typical behavior of oligopolized markets, operating to prevent the emergence of potential competitors. In the case of both Boeing and Airbus, the companies' trajectories are well known, full of episodes of subsidies and intervention by the governments of their home countries ${ }^{13}$. Deferred as national champions in the United States and France, Boeing and Airbus indicate, at the end of 
the market, what happens throughout the segment: both the Canadian Bombardier and the Brazilian Embraer also have a history of direct or indirect aid and subsidies in their production.

In the case of the Brazilian company, history speaks for itself. As a state-owned company until 1994, the transfer of corporate control to the private sector did not cause the government's participation to cease. Whether through contributions from FINEP, BNDES or the existence of the golden share, the Union remained an important partner of the company (FONSECA, 2012, pp. 39-65 ) ${ }^{14}$.

And it is not in a different sense that the golden share is created in the privatization process of the company. As pointed out by Juliana Krueger Pela (2012, p.156), the presence of this security asset fulfills. modality of state intervention in the strategic activities of companies whose shareholding control has been transferred to the private sector. In general, the golden share aims, in this case, to protect the national interest, understood as an internal projection of the State's sovereignty.

Such position is verifiable by the registration of Embraer's own by-laws ${ }^{15}$ and by what is described in article 8 of Law no. 8.031/1990, which created the $\mathrm{NPD}^{16}$. While the legislation provides for the creation of golden shares in situations where the national interest is justified in vetoing certain possible conduct in the company, Embraer's by-laws indicate in a restrictive list the cases where the Union will have veto power. It is noteworthy here that among them is the possibility of transferring shareholding control of the company.

As will be seen below, the regulatory framework described here is in line with the Federal Constitution of 1988 itself. For now, it is important to point out how the operation analyzed here was consolidated. Not only that, but what are the implications for the Administration and the limits imposed on the Union, whether in terms of what is described in the company's by-laws or in the Constitution itself.

In June 2018, Embraer and Boeing signed and made public a memorandum of understanding, indicating the creation of two joint ventures: one for joint operations in the medium commercial aircraft market and the other for the commercial promotion of the KC-390 multi-purpose freighter. ${ }^{17}$ According to the memorandum, New Co. would have Embraer's interest in its capital stock of only $20 \%$, without giving it a seat on the Board of Directors. In return, Boeing would hold the other $80 \%$ of the capital and would have the right to appoint all members of the Board of Directors of the new company. Not only that, New Co. would be a closely-held corporation. On January 10, 2019, the Union gives its approval to the transaction, not exercising its veto power conferred by the special class common stock. At the time of the Extraordinary General Meeting that approved the operation, in January 2019, the obligations pointed to the two involved became public ${ }^{18}$.

The estimated value of the operation is just over $\$ 5.26$ billion. If on the one hand the American company would have total control of New Co., its obligations would not go much beyond a massive capital contribution. Embraer, on the other hand, committed to assigning its intellectual property rights for its new family of jets (E-Jets) to New Co. The latter, in turn, could also assign its intellectual property to the Brazilian company, despite not having any patents or software at the time of its foundation. The design of the new company can be seen in the image below:

FIGURE 1

SHAREHOLDING COMPOSITION AND DETAILS OF THE BOEING X EMBRAER TRANSACTION OWN PREPARATION BASED ON INFORMATION FROM THE JANUARY 24, 2019 AGE HANDBOOK

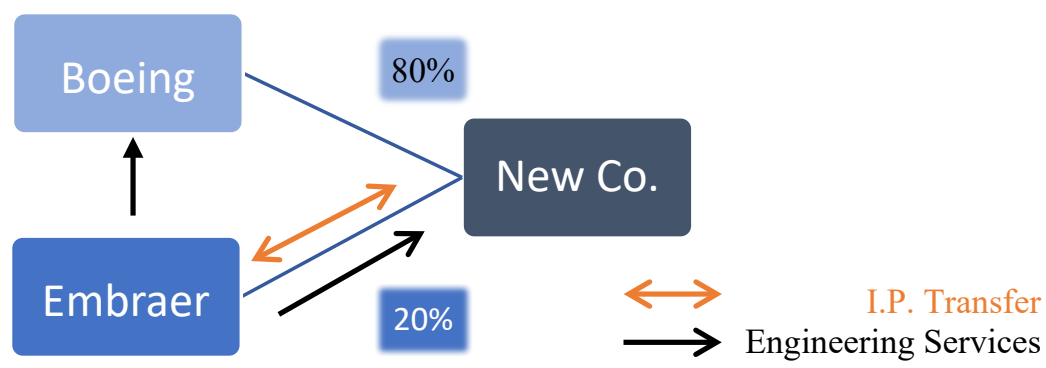


In the case of the joint venture $\mathrm{KC}-390 \mathrm{JV}$, the operation consisted of the formation of a new limited liability company $(L L C)$ based in Delaware, USA. EB DEFENCE LLC has $51 \%$ of the capital contributed by the Brazilian company and the remaining $49 \%$ by Boeing. Its Board of Directors has five members, four of them appointed by Embraer. ${ }^{19}$

The picture below indicates the structure of the KC-390 JV after the entire operation is completed: ${ }^{20}$

\section{FIGURE 2 \\ STRUCTURE OF THE KC-390 JV AFTER COMPLETION OF ALL STAGES OF THE OPERATION}

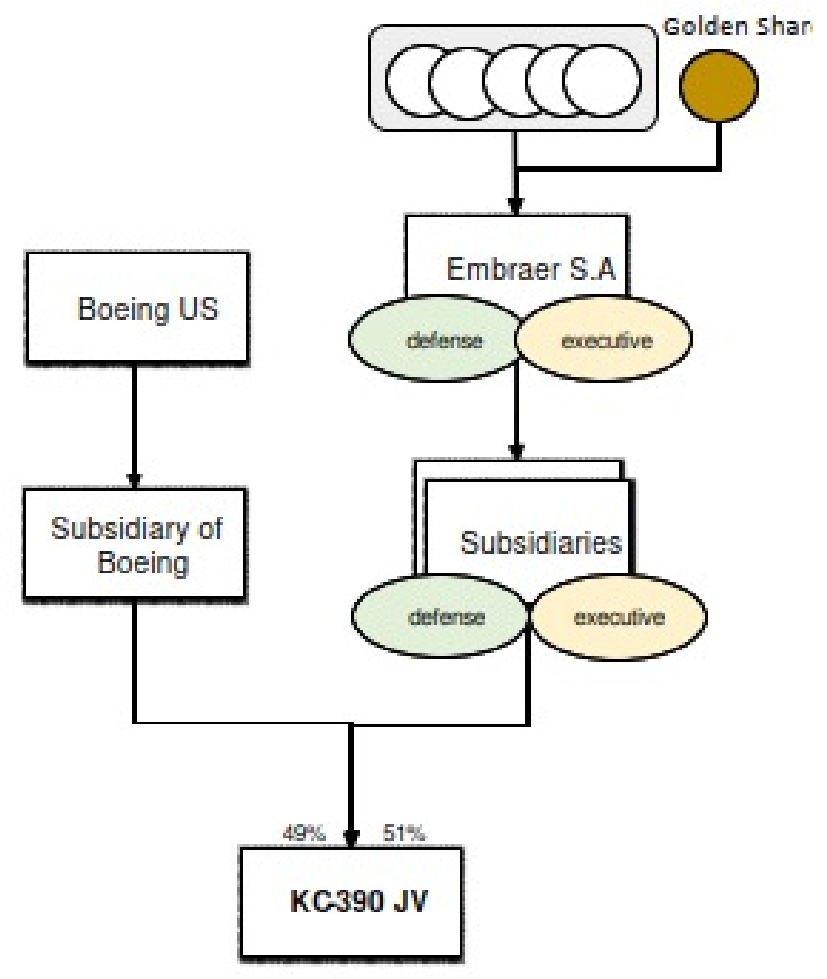

Source: Embraer Extraordinary General Meeting Manual of January 24, 2019

In all, the Master Transaction Agreement (MTA) provided for the execution of seven ancillary agreements $^{21}$ and also instituted a series of other operational agreements, summaries of which are available in the manual. ${ }^{22}$

As pointed out initially, Embraer's by-laws provided for the transfer of shareholding control and changes in military programs. In this case, the creation of New Co. forced the Brazilian company to transfer its specialized workforce through direct contracting, without any counterpart from the alleged U.S. partner. Furthermore, the Intellectual Property License Agreement provided that Embraer would transfer all sorts of patents, including software, free of charge, as pointed out in the AGE Manual of January $24^{23}$ :

As for the corporate structure of the former New Co. (now Boeing Brasil), the aforementioned Manual indicates on page 19 what the control structure of the new company will be: 
FIGURE 3

STRUCTURE OF NEW CO. (BOEING BRAZIL) AFTER THE COMPLETION OF ALL STAGES OF THE OPERATION

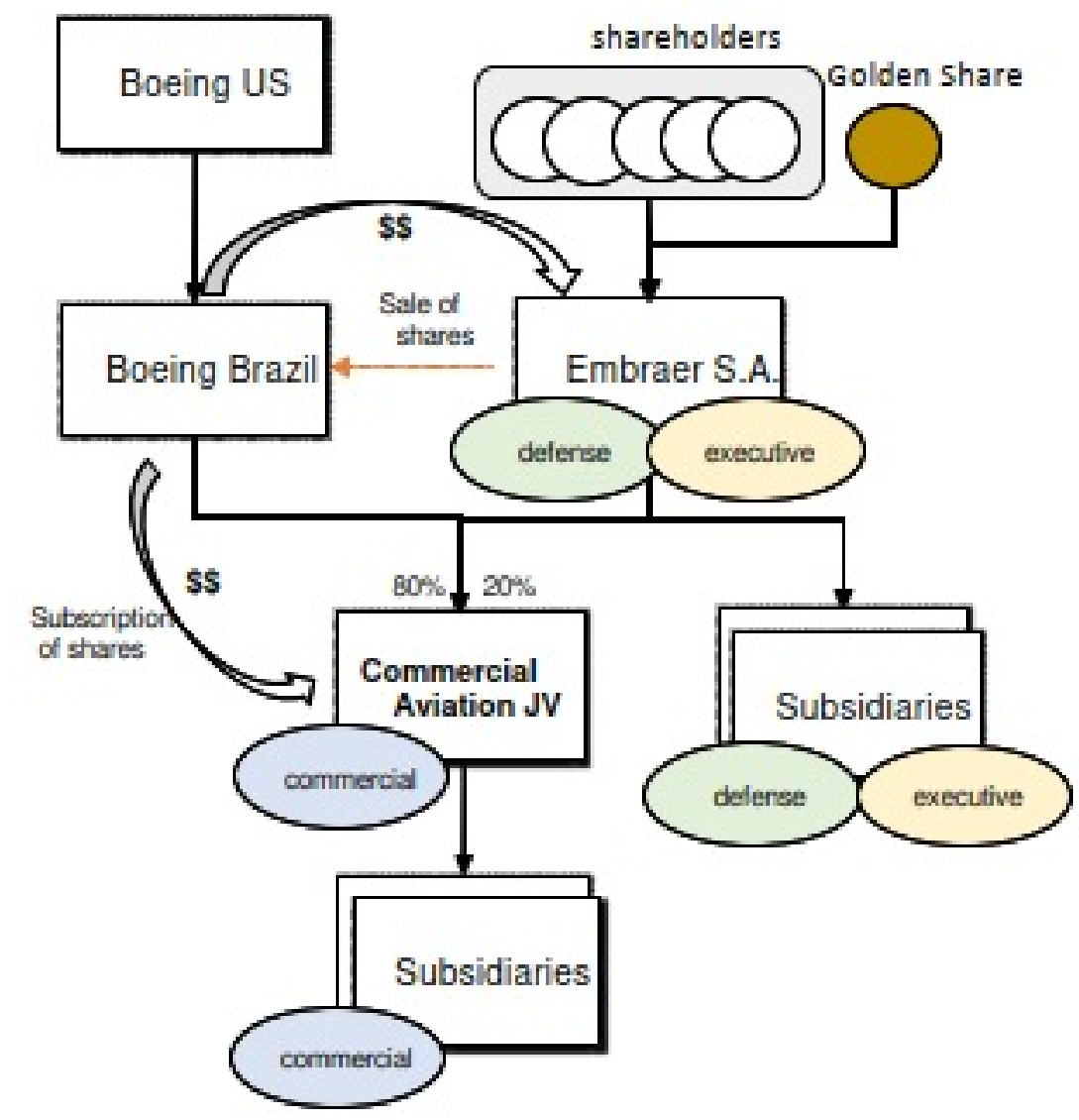

Source: Embraer Extraordinary General Meeting Manual of January 24, 2019

As stated in article 167 of the Brazilian Civil Code, a simulated juristic act is null and void. Furthermore, subsection II of $\S 1^{\circ}$ of the same article points out that simulation will occur in the cases where it contains a declaration, confession, condition or clause that is not true.

What we see here is that under the pretense of constituting a joint venture there is in fact the transfer of the entire production of the Brazilian company's new line of jets to a new company, controlled by the US company Boeing. Furthermore, the unilateral transfer of Embraer's intellectual property to Boeing Brazil, without any counterpart from Boeing, indicates that the industrial design available today and future Embraer creations in jets of 50 seats or more may be used by Boeing Brazil. This is therefore an indirect transfer of corporate control, constituting a simulated legal transaction.

Not only that, the creation of the KC-390 JV provides that the final production of the multi-mission military aircraft, which has been financed since its conception by BNDES through the Growth Acceleration Program (PAC), will necessarily take place in the United States of America, significantly changing the production program of the military aircraft.

Moreover, in both operations, the Union's control over the production of the commercial and military sectors will no longer be under the special class share held by the Union. The reconfiguration of Embraer's production structure renders the golden share innocuous, causing its de facto extinction. In this case, it should be noted that the golden share was provided for by law, therefore, approved by the National Congress, and it is up to the Federal Legislature to deliberate on the case. This is the principle of the 
parallelism of forms, which implies that the Public Power may modify a legal rule under the same rite that created it. Under the cloak of the principle of legality, the parallelism of forms is a condition for the control of the Administration's acts, preventing the Legislative Branch's deliberations from being altered or suppressed by an official act of the Executive Branch, for example.

Within this framework, one must also question the limits of the Administration's discretionary power. It is known that the power conferred to the Public Administration constitutes a duty-power, founded on the principle of supremacy of public interest (MELLO, 2014, pp. 99 and ss). In view of the principle of legality, inscribed in art. 37 of the Federal Constitution, discretion is limited by the entire national legislative framework. Thus, once the scenario described by the norm is configured, the Administration must comply with it, and the use of its discretionary powers is only allowed within the limits imposed on it. According to what was presented in the case study of this article, there are at least two situations that would imply a veto by the Federal Government: the alteration of military programs and the indirect transfer of corporate control, described in items III and IV of article 9 of the company's Bylaws. However, the golden share is inserted in a broader constitutional context. Its preservation is also a constitutional command and implies, in the concrete case, the maintenance of national sovereignty.

\section{The Extinction of the Golden Share and National Sovereignty in the 1988 Federal Constitution}

The Federal Constitution of 1988 brings, expressly, the transformation of social structures and seeks to systematize the legal structure of the Brazilian economy (BERCOVICI, 2005, p.30). In this sense, it is interesting to mention the finalist perspective of Oscar Asenjo (1984, pp.101-120) that is brought by Bercovici (2011, p.210) when stating that: "the economic constitution has as its functions the ordering of economic activity, the satisfaction of social needs and the direction of the general economic process". Within this finalist perspective, the author asserts that the function of ordering the economic activity concerns the institution of the economic public order, that is, the rules of the economic game" (BERCOVICI, 2005, p.30).

Regarding this ordering of the economic game, as reminds us Eros Grau (2015, p.230), the first of the principles of the economic order, which carries, for being part of this constitutional chapter, the purpose of ensuring to all a dignified existence, according to the dictates of social justice, is the economic sovereignty (art. 170, I). Gilberto Bercovici (2008, pp.22-24) when dealing with this concept in the 1988 Federal Constitution associates the idea to the supremacy of a Nation-State characterized by the expression of the will of the people, manifested by a constituent power and consubstantiated by the Constitution.

The principle of economic sovereignty, following Canotilho's concept, is not an option, but an imposing constitutional principle, which fulfills the functions of instrument for the realization of dignified existence and specific objective to be achieved. As an objective, based on Dworkin's epistemology, the principle would assume the function of an objective rule, as a guideline and with a conforming constitutional character. This character is in dialogue, as a foundation, with political sovereignty (art. 1, I), and as a principle of its international relations, national independence (art. 4, I). Added to these is the presence of the domestic market as an integral part of the national heritage, as embodied in Article 219 of the Constitution (SALGADO, 2013, pp.118-150; LUÍS, 2008; BERCOVICI, 2005).

Here, for Grau (2015, pp. 229-230), the concept of economic sovereignty - or, in the author's words, economic national sovereignty - would not represent an economic isolation, but rather a process of modernization of our economic and social system, so that the potentialities of our national economic system are internally explored, in order to break with the Brazilian dependence with respect to the central countries in the world economic system, so that the national patrimony is preserved ${ }^{24}$.

Highlighting the $\mathrm{CF} / 88$ 's concern with the issue of economic dependence and Brazil's position on the periphery of the capitalist system, it is interesting to refer to what Bercovici and Octaviani (2013) bring when they seek the interconnection between the constitutional objectives and the provisions of the Economic Order and the Social Order, as a way of corroborating the statement that the constitution seeks to overcome underdevelopment: 
The task constitutionally assigned to the Brazilian State is (as can be inferred from the commands in Articles 3, 170 and 219 of the 1988 Constitution, among many others), therefore, the overcoming of underdevelopment, of its peripheral condition, that is, a broader, more complex and transforming task than those generally assigned to the traditional Social State, structured in central countries, inspired by the European welfare model or by Keynesian interventions aimed at maintaining the level of employment in the economy. To achieve such a complex task (simultaneously economic, political and cultural, modifying relations between countries and social classes), it is necessary to restructure and strengthen the State, under a democratic and emancipatory perspective, and not dismantle the State apparatus, as has been happening in Brazil since 1994, mainly, with the subsequent institutional modeling of the interests of the financial system, Brazilian and global, repositories of the power relations of underdevelopment.

The adoption of economic sovereignty as an imposing constitutional principle, a guideline and conforming rule, has its relevance maximized when compared to the economic dependence that delays our civilizing process and keeps us in a peripheral situation in the dynamics of the capitalist system.

Embraer, historically, has played a relevant role for the domestic market. The company was created by Decree-Law No. 770, dated August 19, 1969, in order to develop the Brazilian aviation industry ${ }^{25}$. Maria Cecilia Spina Forjaz delineates as a primacy for the creation of Embraer the issue of national security and points out the broad engagement of the military in the Brazilian political process. However, she points out that the creation of the company does not follow an idea that emerged in that historical context, but is similar to the installation of the oil and steel industry that occurred during the Estado Novo, when "the Brazilian state took the initiative to create an infrastructure of energy, transport, steel and communications to support the project of national industrialization" (FORJAZ, 2005, pp. 281-298). Armando Dalla Costa and Elson Rodrigo de Souza-Santos state that the creation of the company crowns a project that, although materialized in the aeronautical sector at the end of the 1960s, went back to the 1930s, especially by military groups of the then Army Air Force and Navy, which viewed the domain of aeronautical technology as fundamental to the country's development. (DALLA COSTA; SOUZA SANTOS, 2010).

The development of aircraft by Embraer sought the purpose of civil and military use (ANDRADE; SILVA FILHO; HILLEBRAND; SUMI, In IPEA, 2016, p.20). Having the production of aircraft started in 1970, partnerships were sought with foreign companies (GOLDSTEIN, 2002, pp. 97-115). Its legal regime was that of a mixed capital company, but with control reserved to the Brazilian government.

Between the years 1975 to 1992, Embraer achieved great business success, especially in the defense sector, having sold in the period from 1975 to 1992 approximately US\$ 1.5 billion in military equipment (ANDRADE; SILVA FILHO; HILLEBRAND; SUMI, In IPEA, 2016, p.20). Despite the commercial success that Embraer had achieved in the military area, the early 1980s were marked by a strong economic crisis that affected Brazil (GOLDSTEIN, 2002, pp. 97-115), with the unfavorable Brazilian scenario and the reduction of the State's power to finance its projects (DALLA COSTA; SOUZA-SANTOS, 2010).

In the 1990s, during the governments of Fernando Collor and Itamar Franco, between 1990 and 1994, with the advance of neoliberalism in the country, which led to a large movement of privatizations of companies that were considered strategic to the State, Embraer was privatized and relevant projects such as the regional jet ERJ 145 were postponed. At that moment, however, although it was privatized, shareholder control remained under national control through the pension funds Previ (20\%), Sistel (20\%) and Bozano, Simonsen Company (20\%), as well as minority partners such as EADS - France and Dassault and the "golden share" of the Brazilian state in order to veto deals that could potentially harm national security (DALLA COSTA; SOUZA-SANTOS, 2010, p.176).

Thus, it can be noted that even with the privatization, there was a concern to safeguard, for reasons of sovereignty, the state control of the company, given its strategic nature. This scenario demonstrates the enormous violation represented by the attempt to extinguish the Golden Share brought in the referenced case involving Embraer and Boeing, clearly representing a spoliation of the national State ${ }^{26}$, which cannot, 
therefore, be a mere discretion of the Federal Executive Power. It also makes the Golden Share represent an even more apt instrument to avoid such spoliation.

In his work "L' ordine giuridico del mercato", Natalino Irti (2004) teaches us that the constitution cannot be seen in pieces. In this sense, the administrative constitutional principle of the parallelism of forms is valid to the economic order, which in the words of Paulo Bonavides (2006, p.206) represents the imposition that: "a juridical act is only modified through the use of forms identical to those adopted to elaborate it". Thus, the field of dialogue for the legislative change tending to the delivery of a state company to foreign capital, whatever the mode of corporate reorganization adopted (merger, spin-off, acquisition, joint venture, etc.), is the National Congress. Furthermore, this connected vision of constitutional principles also allows us to affirm that, as guardian of the constitution, in a subsidiary character, it is not the option of the Supreme Federal Court to manifest itself in a way that makes the maintenance of its postulates a reality, but its primary function.

Although the current national conjuncture is of "constitutional breakdown" ("Verfassungsdurchbrechung") (BELLO; BERCOVICI; LIMA, 2018), since the catalysis of the fraying of the 1988 text, in the post-impeachment period. The legal way out of the underdevelopment condition passes through, as a goal of the constitution itself, according to Gilberto Bercovici $(2005$, p. 69) by a widening of the state functions and a and readaptation of its organs and structure. This is because, as Celso Furtado (1999) states in his essay on 'The Reconstruction of Brazil', the country needs long-term structural reforms. These reforms should have as strategic objectives: to revert the process of patrimonial and income concentration that is at the root of the social distortions that characterize Brazil; to break the backwardness in investments in the human factor, which translates into extreme disparities between salaries of specialists and those of common workers; and to understand how Brazil would insert itself in the globalization process. In this way, the golden share, through its veto power and having as social actors the three powers, within the limit of their designations, should serve to preserve the economic sovereignty in order to agree with long-term strategic reforms that break with our national condition of dependence, and not serve the surrender with austere pretensions that, as Bercovici and Massoneto (2007, pp.79-89) teach us, inverted the directive constitution, armored the financial constitution and agonized the economic ${ }^{27}$ constitution.

\section{CONCLUSIONS}

This article analyzed the golden share in Brazil as an instrument of economic sovereignty. It problematizes the possibility of imposing on the Executive Branch the use of the veto power of the golden share in cases where a joint venture of a foreign company with a state-owned company represents a risk to national sovereignty. The hypothesis raised was that based on the principle of economic sovereignty (art. 170, I), there would be an express obligation to the administration to veto, in the case where a joint venture of a foreign company with a national state-owned company harms the domestic market (art. 219). Moreover, the existence of a golden share without a veto power, which translates itself onto an obligation for the Public Administration, is nothing more than fool's gold.

It was seen that economic sovereignty, as an imposing constitutional principle and a guideline with a conforming character, is not a mere option, and should be issued in cases where a corporate operation between a foreign and a national company violates the country's economic sovereignty.

It was found that in the most relevant case of the formation of a joint venture of a foreign company with a national company, there was actually the transfer of the entire production of the Brazilian company's new line of jets to a new company, controlled by the American company Boeing. Furthermore, in the operations contained in the agreement, the Union's control over production in the commercial and military sectors would no longer be under the golden share held by the Union. Thus, the reconfiguration of Embraer's production structure renders the golden share innocuous, causing its de facto extinction.

In this case, it should be noted that the golden share, since it is provided for by law, would then be up to the National Congress to deliberate on the cases that tend to its extinction and, alternatively, to the judiciary. 
Therefore, from the deductive analysis of the bibliography used, added to the inductive analysis of the concrete case studied, it is concluded that the extinction of the Golden Share tends to violate the principle of economic sovereignty and the domestic market as national patrimony, thus, in cases where a joint venture of a foreign company with a national company represents a risk to economic sovereignty, the use of the veto power should be imposed on the Executive Power, in case of omission of this power, on the National Congress, and subsidiarily on the Judiciary Power, due to the imposing nature of the constitutional principle of economic sovereignty.

\section{ACKNOWLEDGEMENT}

Translated \& Edited by American Publishing Services (https://americanpublishingservices.com/).

\section{ENDNOTES}

1. It is worth noting that the operation was presented by the companies as a set of joint ventures. However, nothing indicates that it is impossible to treat the operation as an indirect acquisition of Embraer by Boeing.

2. Here the expression national economic sovereignty appears, in dialogue with what Giberto Bercovici proposes, as the supremacy of a Nation-State characterized by the expression of the will of the people, manifested by a constituent power and consubstantiated by the Constitution, in its economic dimension. In the 1988 Federal Constitution, economic sovereignty is represented above all by the postulate of national sovereignty in the chapter that refers to the Economic Order (art. 170, I), but the term also appears as a foundation of the Federative Republic of Brazil (art. 1, IV). (BERCOVICI, 2008, p. 22-24 ). It is not intended here to exhaust the historical discussion of golden shares, or even verify all the powers related to the instrument. Therefore, the questions brought focus on the 'golden share' as an instrument of economic sovereignty of the country. The specific question above becomes extremely contemporary and relevant given the scenario described above.

3. The power of veto in Brazil is a reserve that is given to the Union to decide on strategic issues and of national interest within privatized companies. Thus, even after a privatization has been carried out, due to the public interest and national sovereignty, the Union, through a golden share, would have the power to veto certain decisions that were contrary to the interests of the country.

4. Says the Brazilian Constitution: Article 170. The economic order, founded on the appreciation of the value of human work and on free enterprise, is intended to ensure everyone a life with dignity, in accordance with the dictates of social justice, with due regard for the following principles: I - national sovereignty.

5. Article 219. The domestic market is part of the national patrimony and shall be supported with a view to permitting cultural and socio-economic development, the well-being of the population and the technological autonomy of the country, as set forth in a federal law.

6. The international debate on the financialization of capital is extensive. As Gerald Epstein points out, there are at least three strands of understanding about the phenomenon: those who understand it as the political control of the rentier class over the others, along the line of Hielferding; those who perceive financialization as the dominance of the financial systems of capital markets, and; those who understand it as the dominance of shareholder value over corporate management. For the whole debate, see EPSTEIN, 2007, pp. 3-4. See also on financialization: BRAGA In: TAVARES and FIORI, 1997, p. 196; MASCARENHAS, MENEZES, 2020, pp. 455-584, KRIPPNER, 2005, pp. 173-208; CHESNAIS, 2005, pp. 35-36; PAULANI, 2017, pp. 3032; WILLIAMSON In: WILLIAMSON, J. (Org.), 1990, pp. 7-8; VICENTE, 2009, p.127.

7. An interesting view to define neoliberalism is that of Octavio Ianni (1998, pp. 27-28) when he explains that: "Neoliberalism comprises the increasing and generalized liberation of economic activities, encompassing production, distribution, exchange and consumption. It is based on the recognition of the primacy of freedoms relative to economic activities as a prerequisite and foundation for the organization and functioning of the most diverse forms of sociability, including not only companies, corporations and conglomerates, but also the most diverse social institutions. "Neo" liberalism because it is imposed and generalized on a world scale, reaching even those countries in which socialist regime or centralized economic planning had been experienced or continues to be experienced. Under neoliberalism, the State is reformed both in countries that had been organized in socialist molds and in those that had always been organized in capitalist molds. The state deregulates economic activities, privatizes the state's productive enterprises, and privatizes government 
organizations and institutions in housing, transportation, education, health, and welfare. State power is freed from any and all economic or social enterprises that might be of interest to national and transnational private capital."

8. See also: CASTRO, 2005, p. 143. For a deeper look at the issues of globalization and financialization see: SANTOS; SANFELICI, 2016, p. 7 ; BRAGA, In: TAVARES and FIORI, 1997, p. 196 ; KRIPPNER, 2005, pp. 173-208; CHESNAIS, 2005, pp. 35-36; PAULANI, 2017, pp. 30-32; WILLIAMSON, In: WILLIAMSON, 1990, pp. 7-8; VICENTE, 2009, p.127; FURTADO, 1999.

9. See in this sense also Law no. 9.491, of September 9, 1997 attributed a greater power to golden share to the Brazilian State.

10. The number of aircraft manufacturers can be quite diverse depending on the relevant market analyzed. If unmanned military aircraft are taken into account, for example, the number will be different from the one usually seen. In the case at hand, the framework of commercial aviation will be largely observed, led by Boeing and Airbus. The choice is due to the case under analysis, which is seen by analysts as a response to the operation between Airbus and Bombardier, Embraer's direct competitor in the mid-size jet market on a global scale.

11. Note that the report points to an initial growth of $4.2 \%$ in the first five years, falling to $3.7 \%$ in the following five-year period. For more information see GLOBAL FLEET \& MRO MARKET FORECAST COMMENTARY: 2018-2028, p. 22.

12. Idem ibidem, p. 16.

13. The literature on the excessive aid that both companies received from their governments throughout history is extensive. For a broader analysis, see NEWHOUSE, 2007; IRWING; PAVCNIK, 2004, pp. 223-245 . For a specific analysis of the extensive subsidies given to the companies, see CARBAUGH; OLIENYK, 2004 . For a more detailed analysis of the Boeing-McDonnell Douglas merger, see KOVACIC, 2001, pp. 805-873.

14. It should be noted that the KC-390 multi-mission airplane project was intensively financed by the Brazilian government through FINEP and BNDES itself.

15. As its article 9 points out, The special class ordinary share grants the Union veto power in cases of change in the name of the company or its social object; alteration and/or application of the Company's logo; creation and/or alteration of military programs, whether involving the Federative Republic of Brazil or not; training of third parties in technology for military programs; interruption of the supply of maintenance and replacement parts for military aircraft; transfer of shareholding control of the Company; as well as changes in the body of the bylaws themselves. To access the full bylaws, visit the company's website: https://ri.embraer.com.br/show.aspx?idCanal=Kacx+BqjYTwZmMKBRQu5Yg== Accessed November 15, 2019.

16. The current law that regulates the PND is Law No. 9,491/1997. The privatization of Embraer was regulated by a previous law, Law No. 8,031/1990, which created the National Privatization Plan. In both laws, the provisions are identical. For temporal effect, we cite here the provisions of the rule valid at the time of privatization.

Art. 6th The Director Commission of the National Privatization Program is responsible for

XIII - to suggest the creation of golden shares and the matters they will regulate, under the conditions established in $\S \S 1^{\circ}$ and $2^{\circ}$ of this article;

$\S 2^{\circ}$ The golden share can only be subscribed by the Union.

Art. 8 Whenever there are justified reasons, the Union will hold, directly or indirectly, special class shares in the capital stock of privatized companies, giving it veto power in certain matters, which must be characterized in the companies' by-laws, in accordance with the provisions of Art. 6, item XIII and $\S \S 1$ and 2 of this law.

17. The first was named at the time as New Co. today Boeing Brazil. The second became known as the JV KC390.

18. The information referred to here is available with the Manual for the Extraordinary General Meeting of January 24, 2019, available at:

https://ri.embraer.com.br/list.aspx?idCanal=CLZiEuOUHuNY/qTXw1TllA==

19. See the Manual for the AGM of January 24, 2019, p. 14. As regards the production of the aircraft, the agreement entered into between the parties provides that "The Embraer Company and the Boeing Company will jointly decide where the final manufacturing site of the JV KC-390 will be located (in the United States of America), seeking a no-cost structure that maximizes government incentives, or a minimal cost alternative utilizing the existing facilities of the Embraer Company or the Boeing Company, in which case the KC390 JV will reimburse the applicable partner at whose facility the KC-390 JV's manufacturing facilities will be located for costs actually incurred, including internal costs associated with occupancy of such partner's 
facility (which may be structured as a lease (or sublease), lease or any other arrangement with the KC-390 JV or any of its partners).” Id. at p. 70.

20. Idem ibidem, p. 19.

21. These are the Facilities Use Agreement, General Service Agreement, Engineering Agreement, Research and Development Agreement, Supply Chain Cooperation Agreement, Supply Supply Supply Agreement, and, Intellectual Property License Agreement. Idem ibid, pp. 58-69.

22. Idem ibid, pp. 69 and following.

23. "Embraer and New Commercial Aviation Company will enter into the IP Agreement, the scope of which will be to grant reciprocal licenses of intellectual property (i.e., technology, but not trademark) rights ("IP") in order to enable each party to use certain intellectual property assets of the other party in its operations. Embraer will grant New Commercial Aviation Company a license to use, commercialize and exercise IP rights over all IP owned by Embraer or its affiliates that, prior to the execution of the IP Agreement, was used in connection with the commercial aviation business (the "Embraer IP"). The license will be exclusive in the commercial aviation field, and non-exclusive in the other fields (except for the restriction that Embraer IP cannot be licensed by Embraer to certain entities restricted for 10 years or to certain prohibited persons for the term of the IP Agreement). The license will not encompass Embraer's defense and security field of use, defined as: (a) military fixed-wing transport/cargo aircraft with a maximum take-off weight ("MTOW") of less than 192,000 lbs, (b) light attack fixed-wing and turboprop aircraft with an MTOW of less than 15,000 lbs, and (c) military fixed-wing aircraft and services related to such aircraft for sale to or development by government authorities of Brazil. New Commercial Aviation Company shall grant to Embraer a license to use, commercialize and exercise any IP rights in all IP owned by New Commercial Aviation Company and its subsidiaries from the execution of the IP Agreement (the "New Commercial Aviation Company IP"). The license will be exclusive in the field of Embraer's defense and security uses, non-exclusive in all other fields, and valid only outside the commercial aviation field. Embraer may not sublicense or grant manufacturing rights with respect to the New Commercial Aviation IP to certain restricted entities for the first 10 years or to certain prohibited persons for the term of the IP Agreement. Each party may sublicense the rights licensed to it, subject to the terms of the IP Agreement described above. The Parties shall cause their sublicensees to observe all terms of the sublicense and shall promptly cause each sublicensee to cure any infringement. The Parties may update, modify, enhance, translate, reformat, improve or otherwise create derivative rights to the IP licensed by the other Party, and each Party shall own the technology it develops even if based on licensed IP, and shall not be obligated to license such technology to the other Party. If New Commercial Aviation Company or one of its affiliates which is a company headquartered in Brazil introduces a new aircraft which incorporates Embraer IP and is designed for civilian use and is not capable of being configured to contain 50 or more economy class seats, then Embraer and New Commercial Aviation Company (or its affiliate, as the case may be) will use commercially reasonable efforts to negotiate an agreement whereby Embraer is a preferred business partner of New Commercial Aviation Company (or its affiliate, as the case may be) with respect to such aircraft. If the parties cannot reach an agreement on a particular project, New Commercial Aviation Company (or its affiliate, as the case may be) may launch such aircraft alone or with other partners, without prejudice to future agreements on new projects. Finally, it is emphasized that (i) the IP Agreement shall be governed by and construed in accordance with the laws of the State of New York, United States of America, (ii) any dispute or controversy arising out of the IP Agreement shall be submitted to arbitration before the International Center for Dispute Resolution, and (iii) the obligations assumed or arising out of the IP Agreement shall be subject to specific performance." Idem Ibidem, pp. 67 and 69.

24. One can understand national heritage, in the view of Floriano Marques Neto, as that which is more related to an eminent domain, a power, an expression of national sovereignty. In the words of Hely Lopes Meirelles: As an expression of National Sovereignty it finds no limits other than the legal-constitutional order established by the State itself. This dominion encompasses not only the goods belonging to public entities, but also private property and inappropriate things of public interest. MEIRELLES, 1991. Another relevant view on the subject is that of Tércio Sampaio Ferraz Jr, who proposes to analyze the preservation of the internal market as an integral part of the national patrimony from an unusual standpoint, with the purpose of discussing the behavior of market agents in a model of free competition and free market. FERRAZ, pp. 9598; See the approach brought by SALGADO, 2013, p.96. National patrimony is different from what is established as public patrimony. While the latter can be understood, according to Leon Duguit, as the heritage affected by a collective utility DUGUIT, 930, p.345 Thus, from a theoretical-dogmatic point of view, the maintenance of the national heritage is a condition imposed by the constitutional legislator himself, especially 
to foster the domestic market and the Brazilian industrial economy. SALGADO, 2013. It is, therefore, a constitutional imposition and a condition for the realization of national sovereignty.

25. See what is referred to in Article 2 of Decree-Law No. 770 of August 19, 1969: "EMBRAER will have as its purpose to promote the development of the Brazilian aeronautical industry and related activities, including designing and building aircraft and accessories, components and equipment and promote or perform technical activities related to production and maintenance of aeronautical material, in accordance with programs and projects approved by the Executive Branch.

26. Here spoliation is in the sense of accumulation by spoliation of David Harvey who argues that with the financialization associated with neoliberalism, various mechanisms of spoliation of the state by the private sector have emerged. When we check the examples used by Harvey, we can easily include the case of the delivery of Embraer and all its technology belonging to the Brazilian state to Boeing. To better contextualize the examples related to this concept brought by Harvey, see the following excerpt: "The strong wave of financialization, dominance by finance capital, that was established from 1973 onwards was in all things spectacular for its speculative and predatory style. (...) The corporatization and privatization of hitherto public goods (such as universities), not to mention the wave of privatizations (of water and public utilities of all kinds) that has swept the world, indicate a new wave of "expropriation of the commons". As in the past, the power of the state is often used to impose these processes even against the will of the people. The regression of regulatory statutes designed to protect labor and the environment from degradation has involved the loss of rights. The devolution of common property rights obtained thanks to years of hard class struggle (the right to a state-paid pension, to welfare, to a national health care system) to the private domain has been one of the most egregious policies of spoliation implemented in the name of neoliberal orthodoxy. For Harvey, from this 'financialization' are added to the traditional instruments of primitive accumulation others such as biopiracy, regression of regulatory statutes designed to protect labor, the commodification of nature, the patenting and licensing of genetic material, and the aforementioned privatization of public goods that had previously been administered by the state. HARVEY, 2010, pp.96-97.

27. This mention of the authors in the context of infrastructure was originally brought up in MASCARENHAS, 2020.

\section{REFERENCES}

Andrade, I.O., da Silva Filho, E.B., Hillebrand, G., \& Sumi, M.C. (2016).O fortalecimento da indústria de defesa no Brasil. In Texto para discussão $n^{\circ}$ 2182. Instituto de Pesquisa Econômica Aplicada. Rio de Janeiro: IPEA.

Asenjo, O.J. (1984). La Constitución Económica Española: Iniciativa económica pública versus iniciativa económica privada em la constitución española de 1978. Centro de Estudios Constitucionales, pp. 101-120.

Bello, E., \& Bercovici, G. (2018). LIMA, Martonio Mont'Alverne Barreto. O Fim das Ilusões Constitucionais de 1988? Revista Direito e Práxis. Ahead of print, Rio de Janeiro.

Belviso, F. (1997). La nomina da parte dello stato degli amministratori delle società privatizzate (art. 2, comma $1^{\circ}$, lett. d legge n. 474/1994). In maRaSÀ, giogio (Org.), Profili giuridici delle privatizzazioni (pp. 103-110). torino: g. giappichelli editore.

Bercovici, G., \& Massonetto, L.F. (2007). A Constituição Dirigente Invertida: A Blindagem da Constituição Financeira e a Agonia da Constituição Econômica. Revista de Direito Mercantil Industrial, Econômico e Financeiro, 45, 79-89.

Bercovici, G. (2005). Constituição Econômica e Desenvolvimento. Uma leitura a partir da Constituição de 1988. Editora Malheiros.

Bercovici, G. (2011). Direito econômico do petróleo e dos recursos minerais. São Paulo: Quartier Latin. Bonavides, P. (2006). Curso de Direito Constitucional (18 $8^{\mathrm{a}}$ edição), Malheiros Editores, São Paulo.

Borde, D., \& Poncelet, A. (1994, April). Le noveau programme de privatisation français de 1993 une importante evolution des techniques de mise en vente sur les marchés financiers. Rivista Delle Società, 39(1-2), 269-302.

Carbaugh, R.J., \& Olienyk, J. (2004). Boeing-Airbus Subsidy Dispute: A Sequel. Global Economy Journal, 4(2). 
Castro, L.B. (2005). Privatização, Abertura e Desindexação. A primeira metade dos anos 90. In Economia Brasileira Contemporânea (1995-2014) (pp.139-142). Editora Campos Elsevier.

Cervo, A. (2007). Relações Internacionais da América Latina. Velhos e Novos Paradigmas. São Paulo: Editora Saraiva.

Chesnais, F. (2005). A Finança Mundializada: raizes sociais e políticas, configuração, consequências. São Paulo, Boitempo.

Costa, G.M.M. (2016). O BNDES nos Anos 1987-1990. Memórias do Desenvolvimento, 5(5), 61-106.

Cox, G. (1987). The Efficient Secret: The Cabinet and the Development of Political Parties in Victorian England. New York/London, Cambridge University Press.

Dalla Costa, A., \& Souza-Santos, E.R. (2010). Embraer, história, desenvolvimento de tecnologia e a área de defesa. Revista Economia \& Tecnologia, [S.1.], 6(3).

Duguit, L. (1930). Traté du Droit Constitutionnel (3 edição, vol. III). Paris: Ancienne Librarie Fontemoing \& Cie.

Epstein, G.E. (2007). Financialization and the World Economy. Chetelham, UK: Edward Elgar.

Ferraz, T.S., Jr. (1997, January-March). Regulamentação da Ordem Econômica. Cadernos de Direito Constitucional e Ciência, 5(18). RT, São Paulo.

Fiori, J.L. (2001). O Cosmopolitismo de Cócoras. Educ. Soc. Campinas, 22(77), 11-27.

Fonseca, P.V.R. (2012, June) Embraer: Um caso de sucesso com o apoio do BNDES. Revista do BNDES, (37), 39-65.

Furtado, C. (1999, June 13). A Reconstrução do Brasil. Folha de São Paulo, Domingo. Retrieved September 28, 2018, from http://www1.folha.uol.com.br/fsp/dinheiro/fi13069914.htm

Furtado, C. (1965). Desenvolvimento e subdesenvolvimento (3rd ed.) Rio de Janeiro: Fundo de Cultura.

Furtado, C. (1983). Teoria e Politica do Desenvolvimento Econômico. São Paulo: Abril Cultural.

Goldstein, A. (2002). EMBRAER: From national Champion to global player. CEPAL Review, (77), 97115.

Grau, E.R. (2015). A Ordem Econômica na Constituição de 1988: Interpretação e crítica (12th ed., p.230). São Paulo: Malheiros.

Harvey, D. (2010). The New Imperialism. Trad. Adail Sobral and Maria Stela Gonçalves (4th ed.). Loyola: São Paulo.

Ianni, O. (1998). Globalização e Neoliberalismo. São Paulo em Perspectiva, 12, 27-32.

Irti, N. (2004). L'Ordine Giuridico del Mercato (5th Edizione). Roma: Laterza.

Irwing, D.A., \& Pavcnik, N. (2004, December). Airbus versus Boeing revisited: International competition in the aircraft market. Journal of International Economics, 64(2), 223-245.

Kovacic, W.E. (2001). Transatlantic turbulence: The Boeing-McDonnell Douglas merger and international competition policy. Antitrust Law Journal, 68(3), 805-873.

Lijphart, A. (1999). Patterns of Democracy. Government Forms and Performance in Thirty Six Countries. New Haven, Yale University Press.

Marques Neto, F.A. (2008). O Regime Jurídico das Utilidades Públicas: Função Social e Exploração Econômica. São Paulo: Tese de Livre Docência.

Mascarenhas, F.S. (2020). A Regulação Jurídica da Integração dos Modais de Transportes no Brasil: $O$ Sistema Nacional de Viação como instrumento para a superação do subdesenvolvimento. (p. 254). Dissertação (Mestrado). Faculdade de Direito, Universidade de São Paulo, São Paulo, 2020.

Mascarenhas, F.S., \& Menezes, D.F.N. (n.d.). Financeirização, Acumulação por Espoliação e Desigualdades Sociais e Regionais. Revista Brasileira de Direitos Fundamentais \& Justiça, 14(42), 455-484.

Meirelles, H.L. (1991). Direito Administrativo Brasileiro (16 edição). São Paulo: Revista dos Tribunais.

Mello, C.A.B. (2014). Curso de Direito Administrativo (31 ${ }^{\mathrm{a}}$ Ed.). São Paulo: Malheiros.

Luís, A.O. (2008). Recursos Genéticos e Desenvolvimento: os desafios furtadiano e gramsciano. Tese (Doutorado em Direito Econômico e Financeiro). São Paulo: FDUSP.

Newhouse, J. (2007). Boeing vs. Airbus. New York: Alfred A. Knopf. 
Pela, J.K. (2012). Golden Shares in Brazilian Corporate Law. São Paulo: Quartier Latin.

Pela, J.K. (2012). As Golden Shares no Direito Societário Brasileiro. São Paulo: Quartier Latin.

Salgado, R.O. (2013). Constituição e Desenvolvimento: o Mercado Interno na Constituição de 1988. Dissertação (Mestrado em Direito Econômico e Financeiro) - Faculdade de Direito, Universidade de São Paulo, São Paulo.

Salgado, R.O., Mascarenhas, F.S., \& Oliveira, M.V. (2020). A ação de classe especial como instrumento de soberania econômica: Uma análise do caso brasileiro. Revista da Faculdade de Direito do Sul de Minas, 36(2), 1-27.

Silva, L.A. (2000, April/June). Transferência de ações ordinárias da Empresa Brasileira de Aeronáutica S.a. - EMBRAER - Dos acionistas controladores da companhia a empresas francesas. Revista de Direito Bancário, (8), 197-217.

Sodi, J. (1996, March/June). Poteri Speciali, Golden Share e False Privatizzazioni. Rivista delle Società, Milano, 41(2-3), 368-404.

Tavares, A.R. (May-August). Facções privadas e política econômica não-democrática da ditadura brasileira. Revista Brasileira de Estudos Constitucionais - RBEC, 9(32), 1047-1066.

Vicente, M.M. (2009). História e comunicação na ordem internacional. São Paulo: Editora UNESP; São Paulo: Cultura Acadêmica.

Wynman, O. (2018). Global Fleet \& Mro Market Forecast Commentary: 2018-2028. Retrieved November 15, 2019, from https://www.oliverwyman.com/content/dam/oliverwyman/v2/publications/2018/January/20182028_Global_Fleet_MRO_Market_Forecast_Commentary_Public_Final_web.pdf 